\title{
A Computerized Assessment of Verbal and Visuospatial Memory (Dys)functions in Patients with Rheumatoid Arthritis [Response to Letter]
}

This article was published in the following Dove Press journal: Psychology Research and Behavior Management

\section{Laura Visu-Petra}

Department of Psychology, Babeș-Bolyai University, Cluj-Napoca 400015, Romania
Correspondence: Laura Visu-Petra Email laurapetra@psychology.ro

\section{Dear editor}

Thank you for the opportunity to reply to the letter you received about our paper "A Computerized Assessment of Verbal and Visuospatial Memory (Dys)functions in Patients with Rheumatoid Arthritis". 'We appreciate Ketut Andika Priastana's comments and interest towards our paper. However, we are not entirely convinced that responding to the minor issues brought up would make a substantial contribution to the paper, given the brevity encouraged by the journal and the fact that we used standardized (and widely known) clinical and neuropsychological tests, and referred the reader to the original source for details.

Firstly, we do not consider that the absence of explaining in detail two of the most widely used clinical instruments, the Disease Activity Score-28 using CRP (DAS28CRP) and the Health Assessment Questionnaire (HAQ), represents a shortcoming of the current article. Both these measures have already been extensively validated as feasible tools to assess disease activity and functional status in patients with rheumatoid arthritis. The papers by Scanlon et al, ${ }^{2}$ Mitrović et al, ${ }^{3}$ Tada et $\mathrm{al}^{4}$ are only some examples of studies in which the instruments have been used and mentioned as such, without further detailed explanation.

Secondly, CANTAB tests were administered as specified in the procedure from the test manual, ${ }^{5}$ cited as such in the paper and not modified (except for the translation of the items into Romanian which was approved by the test publisher). We do not see why the reference indicated in the letter would be more valid in specifying these administration steps as compared to the CANTAB manual.

We thank again the reader for their interest and comments about our work and the Editor for bringing them to our attention.

\section{Disclosure}

The author reports no conflicts of interest in this communication.

\section{References}

1. Petra CV, Visu-Petra L, Buta M, Tămaș MM, Benga O, Rednic S. A computerized assessment of verbal and visuospatial memory (Dys)functions in patients with rheumatoid arthritis. Psychol Res Behav Manag. 2020;13:619-629. doi:10.2147/PRBM.S261312

2. Scanlon EM, Mankad R, Crowson CS, et al. Cardiovascular risk assessment in patients with rheumatoid arthritis: a correlative study of noninvasive arterial health testing. Clin Rheumatol. 2016;36(4):763-771. doi:10.1007/s10067-016-3515-3 
3. Mitrović J, Morović-Vergles J, Horvatić I, Badžak J, Stojić M, Gamulin S. Ambulatory arterial stiffness index and carotid intima-media thickness in hypertensive rheumatoid patients: a comparative cross-sectional study. Int J Rheum Dis. 2015;20(12):1998-2002. doi:10.1111/1756-185X.12613

4. Tada M, Yamada Y, Mandai K, Hidaka N. Correlation between frailty and disease activity in patients with rheumatoid arthritis: data from the CHIKARA study. Geriatr Gerontol Int. 2019;19(12):1220-1225. doi:10.1111/ggi.13795
5. CANTABeclipse Test Administration Guide. Manual Version 3.0.0. Cambridge Cognition Limited; 2006.

Dove Medical Press encourages responsible, free and frank academic debate. The content of the Psychology Research and Behavior Management 'letters to the editor' section does not necessarily represent the views of Dove Medical Press, its officers, agents, employees, related entities or the Psychology Research and Behavior Management editors. While all reasonable steps have been taken to confirm the content of each letter, Dove Medical Press accepts no liability in respect of the content of any letter, nor is it responsible for the content and accuracy of any letter to the editor.

Psychology Research and Behavior Management

Dovepress

\section{Publish your work in this journal}

Psychology Research and Behavior Management is an international, peer-reviewed, open access journal focusing on the science of psychology and its application in behavior management to develop improved outcomes in the clinical, educational, sports and business arenas. Specific topics covered in the journal include: Neuroscience, memory and decision making; Behavior modification and management; Clinical applications; Business and sports performance management; Social and developmental studies; Animal studies. The manuscript management system is completely online and includes a very quick and fair peer-review system, which is all easy to use. Visit http://www. dovepress.com/testimonials.php to read real quotes from published authors. 